\title{
LOUIS DUMONT, A COMPARAÇÃO DAS SOCIEDADES E O DIÁLOGO CULTURAL
}

Encontrar-se-á aqui um chamado à releitura de Louis Dumont, destinado a todo antropólogo em confronto com suas observações de campo, mesmo que esse campo o tenha conduzido para muito longe dos estudos indianistas ou da história das ideologias ocidentais. Trata-se de reconhecer toda a importância do método holístico geral proposto por Dumont para a disciplina sociologiaantropologia.

\section{A GRANDE DIVISÃo OU O MÉTODO HOLístICO}

Há muito tempo, eu distingui, eventualmente com certa ênfase, dois grandes conjuntos de ensinamentos derivados de Louis Dumont. O primeiro decorre de suas análises, a um só tempo antropológicas e históricas, do contraste entre o que lhe pareceu caracterizar a ideologia indiana (o "sistema de castas"), por um lado, e, por outro, as ideologias ocidentais. Se prosseguirmos na mesma direção, porém indo mais adiante que ele, correremos o risco de chegar a uma grande divisão entre sociedades "holísticas" e sociedades "individualistas" (Tcherkézoff, г993a: I48, n.9).

Dumont não chegou ao fim do caminho, pois no fundo continuava na incerteza que já era aquela de seu mestre, Marcel Mauss. Este último via-se confrontado com a comparação das maneiras pelas quais a dádiva se realiza, sendo levado a distinguir, por um lado, "as nossas sociedades do Ocidente" (contemporâneas ou antigas) com a sua "economia individual e do puro interes- 
se", fundada no princípio do "contrato individual puro", e, por outro lado, as sociedades "ditas primitivas", "arcaicas" ou "elementares", em que as trocas cerimoniais ocorrem "de clã para clã", acrescentando eventualmente formas intermediárias "evoluídas" ou de "grande civilização". Relendo mais atentamente Marcel Mauss, nota-se como o fundador da antropossociologia francesa viu-se forçado a distinguir essas categorias para a sua demonstração no âmbito do Essai sur le don, ao mesmo tempo em que se recusou, muito felizmente, a tirar uma conclusão definitiva no que tange a uma tipologia das sociedades (Tcherkézoff, 20I6: 5I-67, I79-I82). Evolucionismo e grande divisão ou, ao contrário, um meio de se abrir para um método em seguida aplicável a todas as sociedades? As proposições de Mauss acerca da "história da moeda" ilustram perfeitamente essa ambivalência (Tcherkézoff, 20I6). Assim sendo, não deve causar espécie encontrá-la posteriormente em Dumont.

Com efeito - e trata-se do segundo conjunto de ensinamentos derivados de Louis Dumont -, o autor de Homo Hierarchicus elaborou igualmente o que é possível denominar "holismo metodológico", que alimenta uma antropologia aplicável a toda e qualquer sociedade, seja ela holística ou individualista, quer esteja ancorada no mundo ocidental-global contemporâneo ou em lugares ditos "longínquos". Esse é o método sobre o qual falaremos.

\section{LOUIS DUMONT E A OCEANIA}

Previamente, um breve lembrete histórico é bem-vindo no intuito de explicar a reaproximação ocorrida entre Louis Dumont e antropólogos estudiosos da Oceania, entre os quais eu mesmo. Embora alguns estudiosos da Oceania e igualmente certos especialistas nas ilhas do Sudeste Asiático ou até mesmo da África tenham começado a ler Dumont e em seguida a se beneficiar de inúmeras discussões com a participação dele, isso ocorreu em função de circunstâncias imprevistas.

No início dos anos I970, em torno de Daniel de Coppet, que realizava pesquisas na Oceania, nas Ilhas Salomão, colegas - que haviam igualmente se tornado amigos -, especialistas em outras áreas culturais, haviam se encontrado por ocasião de cursos e seminários no que era então um lugar de novos ares para a antropologia social: o campus de Nanterre (Universidade Paris-X). Em I976, eles criaram um grupo de pesquisas temporário reconhecido pelo Centre National de la Recherche Scientifique (CNRS): "Antropologia Social da Fronteira entre o Mundo Indonésio e o Mundo da Oceania", rebatizado em I978 "Estruturas Austronésias da Ideologia e da Troca", posteriormente reconhecido, em I 982, como laboratório permanente sob uma designação que não deixaria ninguém indiferente: "ERASME - Equipe de pesquisa de antropologia social: morfologia, trocas". Durante a segunda metade dos anos I970, o grupo organizou um seminário na Universidade Paris-V, que antropólogos aprendizes, como eu próprio, começaram a frequentar. 
Dos "anciãos" do grupo, Jean-Paul Latouche era e continua sendo um grande leitor de antropologia, em todos os campos geográficos. De acordo com Daniel de Coppet, ${ }^{\mathrm{I}}$ Jean-Paul Latouche chegou certo dia dizendo ao grupo que cada um deveria ler Homo Hierarchicus (Dumont, I966), que ele próprio acabara de descobrir. Latouche trabalhava na Micronésia e, evidentemente, interessavase bastante pelas questões de status na organização social dessas sociedades, e considerou a abordagem de Dumont a propósito das questões concernentes à distinção entre status e poder na Índia muito útil. $\mathrm{Na}$ época, para todas as questões referentes às hierarquias sociais, a escola dominante, ou mesmo a única, era a escola britânica da social stratification. Dumont mostrava como as ferramentas de análise das desigualdades estratificadas não podiam dar conta dos sistemas nos quais o status de cada um somente faz sentido como elemento diferenciado, inscrito em um todo único, em suma, em um sistema inteiramente organizado por relações todo/parte. ${ }^{2}$

Certo tempo depois, ocorreram diálogos pessoais e, fato inesperado, Louis Dumont manifestou interesse pessoal em conhecer melhor os trabalhos desse grupo. A meu ver, e sem que eu possa me apoiar nos propósitos explícitos sustentados por Dumont, duas circunstâncias tiveram influência. O encontro com de Coppet sobre a história das ideias na Europa e o interesse de Dumont pelas sociedades longínquas, ainda desconhecidas dele.

Parece-me que Dumont e de Coppet compartilhavam questionamento idêntico a propósito da ideologia alemã na história europeia dos séculos XIX e XX. Circunstâncias pessoais (a experiência dolorosa e direta da guerra) e um questionamento em comum acerca do que teria sido capaz de criar esse monstro em que se constituiu a ideologia nazista aproximaram os dois homens ${ }^{3}$ (é conhecido o lugar ocupado por esta questão nos escritos de Dumont ${ }^{4}$ ) durante esses anos e posteriormente, quando Dumont preparava Homo Aequalis II: l’Idéologie allemande, lançado em I99I.

Por outro lado, Dumont demonstrava igualmente expressivo interesse teórico pelas sociedades ou, digamos, pelo tipo de sociedade estudado por esse grupo reunido por de Coppet. Diante de mim ele jamais evocou diretamente o vínculo com as questões que Mauss havia levantado acerca da comparação das sociedades; entretanto, esse vínculo parece evidente. Como sabemos, Dumont foi aluno de Mauss e dele guardou várias coisas - a ambição sociológica (o valor supremo da explicação dos fatos humanos pela instituição em sociedade), a paixão pela etnografia comparativa, além de igualmente todo o questionamento sobre a particularidade da ideologia "moderna": invenção radical ou não? E ainda, tratar-se-ia de uma oposição com dois ou com três termos, aquela postulada entre os modernos e os outros? ou, então, em meio aos "outros" não seria necessário distinguir as "civilizações", por um lado, e as sociedades "elementares" ou "arcaicas", por outro? Dumont encontrara, na Índia, a categoria maussiana das "grandes civilizações". Mostrava-se curioso em conhecer 
melhor as sociedades mais longínquas/simples/elementares. No grupo dirigido por de Coppet, ele encontrou um meio de discutir, mais proximamente com pesquisadores, todos habituados ao estudo aprofundado e de longa duração sobre essas sociedades, por assim dizer, longínquas.

A interação com Dumont, contudo, não se limitou a esses diálogos intelectuais. Dumont participou estreitamente do seminário do grupo de trabalho reunido em torno de Daniel de Coppet, desde meados dos anos I970. Quando em I976 esse grupo - certamente comparativo em suas ambições, ainda que focado na Oceania e no Sudeste Asiático - submeteu ao CNRS seu pedido de reconhecimento primeiramente como grupo temporário, de Coppet solicitou a Louis Dumont que assumisse a direção. Dumont aceitou e permaneceu na função até a criação do ERASME em I982, momento em que quis passar o bastão administrativo a de Coppet.

\section{A COMPARAÇÃO DAS SOCIEDADES (1): A “TOTALIDADE SOCIAL”}

Encontramos em Dumont resposta ao que era a minha questão: como iniciar in loco um diálogo antropológico? Antes de citar Dumont, é possível resumir. Trata-se de adotar um procedimento com dois níveis de interpretação. Em primeiro lugar, é imprescindível perceber a totalidade do sistema social que se pretende interpretar, antes de traduzir ainda que apenas um só elemento (diremos: "nível I"). Paulatinamente, o observador chega então no ponto de ser englobado nessa totalidade. Dela transparece o inevitável etnocentrismo que o animava, sob as "cores" da cultura específica encontrada ("nível 2"). Um diálogo pode então começar.

Esse diálogo ou parceria é a única prova da qual dispomos de um certo êxito empírico da pesquisa antropológica. Por um lado, trata-se, invariavelmente, de um procedimento interpretativo; por outro, essa constatação não nos deve impedir de estabelecer um nível de verificação possível. ${ }^{5}$ Este último encontra-se não em uma pretensa objetividade, mas no diálogo.

\section{A contradição inicial}

A ambição da antropologia social levanta um problema particular. Com efeito, é o universalismo humanista - a convicção da unidade do gênero humano - que fundamenta a ambição comparativa da antropologia: as sociedades humanas são comparáveis, pois são compostas de seres humanos. Não é, todavia, o ser humano como indivíduo sempre similar que é o objeto da comparação, mas, antes, as "sociedades". Essa é a razão pela qual Mauss e, depois, Dumont preferiram falar em "sociologia" (comparativa). ${ }^{6}$ Ora, o universalismo só fornece como ferramentas de trabalho a ideia de indivíduo e aquela de semelhança entre comportamentos. Como observar então as sociedades e as variações nas formas de identidade (esses múltiplos "nós", esses sistemas de pertencimento "identitário") ao mesmo tempo em que se trabalha em prol do universalismo? Como manter juntas a unidade do Homem e a diversidade das sociedades?? 
Primeiramente, notemos que o problema se coloca após uma escolha inicial. É o antropólogo que adota "sociedade" como objeto, é ele que faz a escolha de uma sociologia das identidades coletivas, diferentemente da antropologia física ou da linguística estrutural. Em função dessa escolha, é ele quem coloca a necessidade comparativa. Ele escuta o discurso do "nós", mas igualmente o provoca, pelo fato de vir pessoalmente ao encontro do que denomina "sociedade", seja uma nação ocidental, uma ilha oceânica ou uma "etnia" africana. Ao enfrentar essa relação com os outros, ele imediatamente postula uma assimetria muito particular: aquela entre um grupo (a unidade de estudo que ele considera "sociedade") e sua individualidade, especificando que essa individualidade é representativa do universalismo humanista que evoquei.

Essas poucas evidências já foram expressas por Mauss, em uma forma que Dumont frequentemente citava: "Na realidade, Marcel Mauss definiu a antropologia social antes de I900. Primeiramente, dizer 'antropologia' consiste em 'postular a unidade do gênero humano'”. Dumont, entretanto, logo acrescentava, continuando a citar Mauss: "Em seguida, 'para oferecer um quadro científico, é preciso considerar as diferenças e, para tanto, é requerido um método sociológico'". ${ }^{8}$

Dumont notava que o valor universalista fora afirmado desde a primeira antropologia do século XIX. A obra, ainda que confusa, do primeiro titular de uma cadeira de "antropologia social", The golden bough, de sir James Frazer, é "um monumento elevado em prol da 'unidade do gênero humano'" (Dumont, I966: 324n.). O preço desse monumento, entretanto, é conhecido: um "intelectualismo", dizia Mauss a respeito de Frazer, pois sua lógica "não considera senão as semelhanças" (apud Dumont, 1966). Retornemos mais de perto ao texto de Mauss:

Quando falamos de estados psicoafetivos [a lógica do "mana", da festa ritualística], pensamos em sociedades definidas e não em sociedade em geral, no povo, nas massas indecisas, numa humanidade difusa, em que as ideias e os sentimentos seriam transmitidos de indivíduos a indivíduos, sabe-se lá de que modo. O povo do qual falam os Völkerpsychologen é uma coisa abstrata... nós diferimos dos antropólogos ingleses [tais como Frazer] e dos psicólogos alemães [a Völker-psicologia]. Eles passam diretamente às semelhanças, buscando em tudo algo de humano, comum; em uma palavra, banal.

$[\ldots]$

O social não é para nós o popular e tampouco o comum. Até mesmo quando se trata de magia e de folclore, jamais perdemos de vista a ideia de que práticas e crenças são específicas de determinados povos, de certas civilizações. Elas sempre têm o colorido particular que assume todo e qualquer fenômeno em cada sociedade... o que proporciona um campo sólido à ciência são fenômenos particulares: sacrifícios, magias, formas de classificação etc. Mas todos os fenômenos particulares têm razões gerais. É através das particularidades das instituições que buscamos encontrar os fenômenos gerais da vida social (Mauss, I968, tomo I: 37-38; grifos e entrecolchetes nossos).

Assim sendo, é imprescindível considerar as diferenças, o que, entretanto, deve-se fazer permanecendo fiel aos princípios da ética universalista - e, portan- 
to, afastando tudo aquilo que contribua para uma grande divisão das sociedades. O objetivo da antropologia, pelo contrário, como observa Mauss nesta última citação, consiste em encontrar as "razões gerais" dos "fenômenos particulares". Para tanto, é mister observar o "colorido" que assume o fenômeno em cada caso.

Evidentemente, esse nível de estudo é determinado pelo plano superior que define o procedimento estruturalista, pois a busca de uma comparação entre sociedades globais é justificada pela certeza prévia da unidade mental universal. Esse nível, entretanto, ainda que subordinado, afirma sua diferença. Antes de poder comparar e notar eventual semelhança entre duas configurações encontradas em duas sociedades, deveremos ter relacionado cada uma dessas configurações à totalidade do sistema de pertencimento da sociedade em questão. Assim, a comparação das sociedades requer condições suplementares em relação ao modo de proceder lévi-straussiano, em que as "formas de pensamento" diferentes são principalmente apreendidas "sob a ângulo das propriedades comuns" (Lévi-Strauss, I962: I7). Seguimos em direção ao nível que nos ocupa, situado acima do relativismo cultural, o qual aprisionaria toda sociedade em uma concha fechada.

\section{A generalização prévia}

Essa escolha do plano de comparação, abaixo do universal mental e acima do relativismo cultural, determina que a generalização prévia - operação sempre necessária para fundamentar uma comparação universalista - não se refira mais ao mental (ao "inconsciente" lévi-straussiano e à "função simbólica"), mas à universalidade das representações de pertencimento a um grupo concreto.

Primeiramente, uma palavra acerca da afirmação inicial: a generalização fundamenta a comparação, e o contrário não é verdadeiro. Há duas maneiras de generalizar. Uma, aparentemente lógica - mas não o é em antropologia -, consiste em observar o maior número possível de exemplos para depois generalizar. Nesse caso, a generalização diz necessariamente respeito aos pontos em comum, e aqui encontramos os defeitos do método que se vale das "semelhanças". O observador só pode encontrar o que ele já sabia (ou já tinha como pressuposto) quando identificava o fenômeno a ser comparado. A outra generalização, efetivamente a serviço do método que se vale das "diferenças (entre sociedades)", consiste em generalizar previamente, com base apenas na própria ideia de "sociedade", para que o campo destinado ao exame das diferenças admita um objeto diferente daquele de "indivíduo", ao mesmo tempo em que evita questionar o universalismo.

Desse lado, encontramos três possibilidades. Temos o funcionalismo da antropologia política, que generaliza pressupondo um organismo equilibrado e que em seguida observa como esse equilíbrio é mantido: por exemplo, "com Estado", "sem Estado" etc. (com o defeito de ter que adicionar elementos vindos da nossa cultura - tais como o "Estado" -, o que rapidamente conduz a abordagem 
para uma tipologia preconcebida). Temos igualmente o estruturalismo de LéviStrauss, que faz do "simbólico" algo dado: por exemplo, não precisamos nos interrogar acerca do "porquê" da reciprocidade social, mas somente sobre o "como". 9 Temos ainda o holismo metodológico aplicado ao social, herdeiro das noções de "sagrado" e de "mana" presentes em Durkheim e Mauss, revisadas à luz da noção de "totalidade", presente em Mauss e posteriormente em Dumont. ${ }^{\text {Io }}$

Claude Lévi-Strauss e posteriormente Françoise Héritier expressaram com veemência a necessidade paradoxal da generalização prévia. Ainda que o propósito focalize o plano de comparação estruturalista, ele nos serve como guia, visto que nosso plano de estudo se situa no nível inferior:

Quanto ao método comparativo, ele não consiste, com frequência tenho salientado, em primeiramente comparar e depois em generalizar. Contrariamente ao que se acredita muito amiúde, generalizar é justamente o que fundamenta e torna possível a comparação. Diante de uma pluralidade de experiências, começamos por buscar em que nível convém se posicionar para que os fatos observados e descritos sejam mutuamente conversíveis. E é somente quando se logra formulá-los em uma língua comum, e graças a esse prévio aprofundamento, que a comparação se torna legítima (Lévi-Strauss, 1988: 179-180; grifos nossos).

Héritier relembra que essa atitude estrutural é justificada porque, fundamentalmente, a progressão do específico para o geral é, para Lévi-Strauss, uma passagem do consciente ao inconsciente. Se alcançamos "a estrutura inconsciente subjacente" a determinada instituição, obtemos "um princípio de interpretação válido para instituições" (Lévi-Strauss apud Héritier, I 992: 4). E acrescenta:

as regras de funcionamento do social estão assentadas sobre o inconsciente ou, se preferirmos, são da alçada do não formulado, da preterição. Para atualizá-las, convém formular hipóteses, decorrentes da comparação ou, ao menos, do conhecimento de grande volume de dados, hipóteses que procedem desses saltos selvagemente especulativos da intuição dos quais falava Einstein (Héritier, 1992: 7).

A comparação que nos concerne, por sua vez, visa à universalidade das representações de pertencimento a um grupo concreto. A generalização prévia que nos é útil diz respeito a esse aspecto. A tradução deve então levar em conta este imperativo holístico: perceber um espaço de pertencimento, ou seja, um "todo". As relações apropriadas para se modelizar um pertencimento são da forma todo/parte, conjunto/elemento, e não mais simples oposições distintivas. Precisamos traduzir o fato de que "eles" (toda a sociedade) constituem uma totalidade vis-à-vis "nosso" individualismo universalista.

\section{A totalidade social: uma noção metodológica}

Então essa totalidade (o objeto "sociedade") é definida como tal por nosso olhar universalista-individualista por contraste com os pressupostos desse enfoque. Trata-se, portanto, de um holismo metodológico e não ontológico-culturalista. Em busca dos fenômenos de pertencimento, buscamos sistematicamente as 
relações a) cuja referência não esteja situada fora do campo relacional e b) que constituam uma interdependência orientada: relações todo/parte. Dizer que a totalidade é metodológica, implica igualmente afirmar que toda e qualquer sociedade, por mais ocidental-moderna que seja, pode e deve ser analisada desse modo (Tcherkézoff, I994a).

Trata-se, por conseguinte, de buscar sistematicamente as relações todo/ parte. Quais as razões pelas quais se faz isso tão pouco na prática antropológica? Acredita-se observar fatos como fatos, fatos "brutos", tão somente distinguindo-os entre si - em oposição distintiva -, para depois se interrogar, em um segundo momento, acerca da valoração relativa do fato observado, em função do contexto em que ele aparece. Em suma, dissociam-se abusivamente o fato e o valor, o que equivale, cabe salientar, a identificar-traduzir mediante projeção etnocêntrica, concedendo em seguida a palavra aos interessados para que nos digam apenas de que maneira, positiva ou negativa, e segundo qual ordem de preferência eles utilizam esse objeto por nós identificado. Ao contrário, em um sistema "total", um fato só tem significação por seu lugar no todo (é só isso que determina seu "valor"). Em vez de separar fato e valor, em lugar de crer inocentemente que a distinção seja uma operação mental neutra quando está relacionada a um todo social, convém se ater, desde o início e unicamente, ao lugar dos homens e das coisas no todo, constituindo-se esse lugar-no-todo na capacidade de cada homem e de cada ideia de representar a identidade coletiva mais fortemente do que outro homem ou outra ideia. Certamente, a antropologia entendeu de longa data que o objeto "sociedade" deve ser descrito como um sistema de relações. Como, porém, não se concentra na análise das relações hierárquicas (todo/parte) no sentido supracitado, ela acredita já observar relações quando, na verdade, está simplesmente identificando as oposições distintivas.

Aqui temos todo um campo de estudos: quais são as ferramentas capazes de dar conta das relações "hierárquicas", no estrito sentido de "relações todo/parte" (o que não tem nada a ver com a desigualdade/estratificação)? Passei vários anos, em número relevante de publicações, desenvolvendo tal instrumental, ${ }^{\text {II }}$ ao mesmo tempo em que mostrava o que ele devia a Dumont e a seu conceito de "oposição hierárquica", a partir de I978, quando Dumont insistiu, mais nitidamente do que em suas publicações anteriores, no aspecto metodológico desse instrumental necessário à antropologia holística. ${ }^{12}$ Publicações mais recentes acumularam os exemplos de campo, oriundos de Samoa, no intuito de ilustrar a vantagem proporcionada por tais ferramentas. ${ }^{13}$ Aqui, em razão da falta de espaço e porque essas publicações estão acessíveis, não desenvolverei sobremaneira o comentário relativo a esse aspecto de nossa discussão e a seus dois principais componentes: a oposição "hierárquica" no sentido da relação todo/parte, em contraste com a oposição distintiva da antropologia estrutural ou funcionalista; e a hierarquia entre "níveis" (de valor), de 
acordo com um modo relacional que Dumont denominou "englobamento". Em contrapartida, aqui desenvolverei o que é a primeira etapa de toda a lógica e de seus desdobramentos, o procedimento: o modo de conceber o engajamento do antropólogo em suas ações de campo, bem como a correlata comparação das sociedades, pois essa primeira etapa não se desdobrou em meus trabalhos já publicados. ${ }^{\mathrm{I}}$

\section{A COMPARAÇÃO DAS SOCIEDADES (2): A DUALIDADE DA OBSERVAÇÃO}

\section{O componente ideológico e o resto}

Convém primeiramente considerar a maneira pela qual Dumont define a dualidade do conteúdo da observação, dualidade que conduz a um modelo do englobamento do observador. A propósito da Índia, Dumont opõe o status de castas ("ideológico" ou às vezes até mesmo uma "religião") e o poder real ("não ideológico"), o qual se manifesta pelo fato de a autoridade fundiária, por exemplo, criar desigualdades concretas, em contradição com a hierarquia das castas. A amplitude da oposição suscitou críticas, e o procedimento é muito amiúde recusado. No fundo, não haveria nisso nada de novo: uma simples paráfrase do modelo sagrado/profano. E, no entanto, tal abordagem apresenta um avanço, em que pese sua forma um tanto inacabada ou até mesmo confusa em alguns casos nos quais ela foi aplicada pelo autor. Com efeito, com sua análise da relação entre status sagrado e poder na Índia, Dumont acrescenta simultaneamente a questão da relação entre a sociedade observada e o observador:

[A propósito da observação na Índia] Nós dissemos que o nosso objeto primeiro era um sistema de ideias e de valores [as noções de "puro/impuro" que hierarquizam as castas]. Nós igualmente reconhecemos, entrementes, no território ou na localidade, o exemplo de um fator [o poder sobre a terra] que, mesmo não estando diretamente inserido na ideologia, intervém no nível das manifestações concretas do sistema de castas...

Justamente aqui se situa o equivalente do que nomeamos relações de força, fenômenos econômicos e políticos, poder, território, propriedade, etc. Esses dados que nós sabemos restituir graças às noções das quais dispomos em função da nossa própria ideologia, poderíamos chamá-los de concomitâncias (comparativas) do sistema ideológico...

Percebemos duas categorias de aspectos de modo distinto, de tal sorte que a distinção entre eles expressa a nossa posição em relação ao objeto. Com efeito, por um lado, é a teoria nativa que nos possibilita atribuir o devido nome às coisas: quando falamos em casta, traduzimos mais ou menos um conceito nativo (jat... ${ }^{15}$ ); se, ao contrário, falarmos em "estratificação social", estaremos introduzindo julgamentos arbitrários (...que casta e classe social são... da mesma natureza...). Por outro lado, se formos capazes de perceber nos fatos outra dimensão, distinta daquela que a consciência nativa considera [no caso, o poder], isso ocorre graças à comparação, graças em primeiro lugar à comparação implícita e inevitável com a nossa própria sociedade. Isso deve estar evidente. 
Assim sendo, devemos proceder em dois tempos: primeiramente ir à escola dos hindus... para ver as coisas como eles... [...]

Mas a ideologia não é tudo. Fato é que a observação de qualquer conjunto local revela uma vida social que, embora seja orientada de modo decisivo pela ideologia, supera esta última simultânea e amplamente... (Dumont, I966: 55-59; grifos e entrecolchetes nossos).

Assim, no caso da Índia, Dumont (I996) veria operando "em todo o conjunto concreto" de castas, "o princípio formal", por um lado, e, por outro, "uma matéria-prima que ele ordena e engloba logicamente, mas não justifica"; esse será "o equivalente daquilo que nomeamos... poder, território, propriedade":

[Porque cada sociedade concreta se nos aparece como uma determinada escolha de valores entre todos os valores concebíveis] Essa escolha dos valores tem como consequência o fato de que alguns aspectos da realidade social sejam clara e conscientemente elaborados, ao passo que outros são deixados à sombra. Para expressar o que a sociedade considerada não expressa, o sociólogo não pode inventar conceitos, pois, quando tenta fazê-lo, ele apenas consegue, tal como no caso da "estratificação" [o conceito da antropologia política anglo-americana dos anos I940-I960; cf. Dumont, 1966: 314n.], traduzir de modo a um só tempo pretensioso e obscuro os preconceitos de sua própria sociedade (Dumont, I966 [1960]: 323; entrecolchetes nossos).

No caso geral, diremos acerca dessas "concomitâncias" (comparativas) do sistema ideológico:

O fenômeno observado tem um componente ideológico e outro que denominaremos residual sem pressuposto ontológico, no intuito de assinalar a maneira pela qual ele é colocado em evidência. O que ocorre no plano da observação $O$, tão logo relacionado a um primeiro plano de referência, [que é] o plano da ideologia I, coloca em evidência outro componente situado no plano residual R: ( $=I+R)$. Da observação e da ideologia nós deduzimos por "subtração" o componente residual empírico de cada fenômeno observado. Evidentemente, o erro está à nossa espreita... (Dumont, I966: 58; aspas do autor).

Denominemos essa equação "a fórmula de Dumont". Ela pode parecer assaz abstrata: $\mathrm{O}=\mathrm{I}+\mathrm{R}$. No que me diz respeito, eu a compreendi por intermédio de Mauss: mesmo que o vocabulário seja muito diferente, pareceu-me que Dumont e Mauss falavam sobre o mesmo método quando, no processo antropológico de observação-interpretação, um dizia "subtração", o outro, o "colorido" particular de um fato social. ${ }^{16}$

Uma expressão ainda mais nítida é formulada por Dumont (I97I) em contexto totalmente diverso, no qual o autor fala da teoria do parentesco em geral, a propósito de uma discussão sobre a "linguagem do parentesco" que pode expressar um sistema "político", assim como no tocante à questão de saber se, como pretendia Beattie, era preciso considerar o parentesco como pura forma pela qual o conteúdo possa ser variável de acordo com as circunstâncias (conteúdo "político", "econômico", etc.): 
...nota-se: primeiramente, que os dados sociais se tornam fatos ou são levados ao nosso conhecimento, sempre e tão somente, por meio de ou graças a ideias (uma linguagem), em seguida, que eles chegam até nós de dois modos diferentes, quer recorramos às ideias dos próprios sujeitos ou às nossas. O postulado de Beattie, que distingue uma forma e um conteúdo, uma "linguagem" e uma realidade substancial, é na realidade uma proposição comparativa: do ponto de vista nativo, há uma linguagem que expressa suficientemente a realidade social; do ponto de vista do antropólogo, ao relacionar implícita ou explicitamente o que ele observa com a sua própria experiência na sua própria sociedade, há algo distinto na realidade observada, diferente daquilo que veem os próprios interessados nela: a oposição... é aquela entre o que é diretamente conhecido nas categorias da sociedade estudada e o que é conhecido indiretamente, por meio das categorias da sociedade do próprio antropólogo (Dumont, I97I: 3I-32; grifo do autor).

Dumont acrescenta que as categorias sociológicas supostamente objetivas não passam com frequência de uma expressão das categorias da sociedade do antropólogo e que a construção de categorias mais objetivas (intuito derradeiro da antropologia como "comparação das sociedades") não poderá ocorrer sem que se multipliquem as comparações no sentido acima: as relações entre o que é conhecido diretamente ("eles") e o que é conhecido por "nosso" intermédio (Dumont, I97I). Em outros termos, a antropologia, quando é uma "sociologia comparativa", torna-se "necessariamente holística", devendo "relacionar de modo construtivo o individualismo do qual somos oriundos e o holismo que predomina em nosso objeto de estudos" (Dumont, I983: I92, I95-199).

Notemos: o holismo é, portanto, a característica do objeto "sociedade" - "a sociedade como universal concreto" (Dumont, I983) - e, assim, um método geral, aplicável a toda e qualquer sociedade. Por conseguinte, a interpretação do "todo", do "nível I" como eu igualmente o nomeio, ou, se quisermos, a interpretação da componente "I", segundo a fórmula dumontiana ( $=I+R)$, deve ser unicamente metodológica.

\section{A generalização prévia sobre o "componente ideológico"}

Deve-se, contudo, acrescentar um ponto fundamental. É bem verdade que determinados postulados de Dumont acerca da dualidade do conhecimento etnográfico podem levar a crer que a primeira fonte de conhecimento não impõe qualquer tipo de problema: o que é conhecido "diretamente nas categorias da sociedade estudada" (a parte "I" da fórmula). Essa é a razão pela qual parece-me que uma hipótese prévia deva ser adicionada, no intuito de permitir que a interpretação escape do etnocentrismo: essas categorias sempre são uma ideologia do pertencimento a um todo. Pois, então, como conduzir uma interpretação operada "diretamente nas categorias" locais sem incorrer no risco de interpretar por assimilação ao que conhecemos?

Estabeleçamos aqui, portanto, que a primeira "generalização prévia" da antropologia metodologicamente holística consista em definir a priori a inter- 
pretação de "I" como um sistema de pertencimento a um todo, um sistema de relações todo/parte. Se seguirmos essa via, será ingenuidade pretender em seguida descobrir o caráter "holístico" da ideologia de uma sociedade. Essa totalidade é o que nós decidimos perceber, em contraste com o nosso universalismo individualista. Veremos mais concretamente do que se trata com o exemplo da sociedade de Samoa, onde pesquisamos. Antes, uma última questão de método.

\section{A mudança social}

Esse modelo dumontiano, assim tornado totalmente "metodológico", bem distante de aprisionar a antropologia em uma visão "dissociada do tempo", como alguns críticos o pretendem, possibilita igualmente conduzir estudos diacrônicos, conseguindo uma vez mais reduzir ao mínimo os preconceitos ocidentais concernentes à evolução das sociedades. Havíamos dedicado uma obra coletiva a essa questão, além de ter exaustivamente desenvolvido o exemplo de Samoa nesse plano diacrônico, logrando assim distinguir o que são transformações que não afrontam o sistema de pertencimento e aquelas que, se vierem a chegar a seu fim, constituiriam realmente uma mudança de sociedade (a partir do momento em que aquilo que é modificado no "nível 2" provoca modificações no "nível I"). ${ }^{\text {I7 }}$

\section{O "COLORIDO" DO FATO SOCIAL ESPECÍFICO: EM SAMOA, POR EXEMPLO}

Para mostrar concretamente a utilidade do modelo, vamos considerar o exemplo da sociedade polinésia de Samoa, onde fui acolhido como antropólogo desde I98I para a realização de minhas pesquisas.

O projeto de trabalhar na Polinésia ocidental remontava a um período anterior. Após alguns estudos com base em documentos voltados para as realezas ou comunidades com chefes "sagrados" na África Oriental, praticamente desaparecidas sob o jugo da colonização, eu estava curioso em ver de perto essas comunidades, sobre as quais era possível ler que estavam plenamente ativas. O projeto estava preconcebido: a noção de comunidades com chefes "sagrados". Porém, nesse ínterim, a partir do seminário do grupo de de Coppet, já mencionado, eu havia lido Louis Dumont e havia me beneficiado das discussões ocorridas no grupo. Tão logo instalado em Samoa, busquei primeiramente e de modo sistemático identificar o sistema mais global que definisse para cada um o seu pertencimento à totalidade social.

Tratava-se em um primeiro momento de perceber os limites da unidade social de pertencimento nesse arquipélago. A priori, poderiam ser todas as ilhas ou uma das entidades políticas separadas pela antiga história colonial (a Samoa Ocidental, independente desde I962, ou o território da Samoa Americana) ou ainda uma única ilha, um distrito, uma cidade, um clã etc. A maneira de cada um se apresentar aos olhos do estrangeiro foi um primeiro guia. O discurso principal do "nós somos" estava focado na palavra Samoa ou antes faaSamoa 
( $f a a$ a à moda de, o que convém para) e o termo designava, a um só tempo, a língua e tudo aquilo que se "deve fazer quando se é samoano". A noção era oposta àquela dos vizinhos, o faaToga, o faaFiti, o faaPapalagi, a identidade dos habitantes de Tonga, Fiji ou ainda dos europeus. Isso, porém, não bastava. Eu notava que, cada vez que samoanos que não se conheciam ou pouco se conheciam se encontravam, eles se dirigiam discursos para indicar a cada um qual é o seu aiga (diremos "clã", para simplificar) e qual é o seu nuu (vilarejo, no sentido de comunidade instituída e não de uma simples localidade geográfica), sem se preocupar com a entidade político-nacional (os dois países-territórios "Samoa") e tampouco com a ilha específica que cada qual habitava.

Um clã pode ter ramificações em todo o país, mas rapidamente se compreende que ele é definido por um nome ancestral fundador (um "título"), o qual deve ser atribuído a cada geração por ao menos um dos membros do clã (então designado "chefe", matai em língua local). Esse título sempre é geograficamente localizado por uma unidade-tronco, a qual é indicada como "pertencente ao vilarejo Tal". O vilarejo é um "círculo sagrado" de títulos. As reuniões formais que animam a vida coletiva de um vilarejo seguem uma ordem de lugares sentados em conformidade com uma hierarquia dos títulos enraizados no vilarejo, quer seja uma reunião dos chefes ou de outras pessoas, mas que se dispõem de acordo com o lugar que o respectivo chefe ocuparia se estivesse presente (Tcherkézoff, 20I7). É preciso salientar o fato: seja qual for o status da pessoa, todos interagem entre si em função do lugar do título do seu clã em relação ao lugar dos títulos aos quais se referem às outras pessoas com as quais Ego interage.

Quase invariavelmente, toda e qualquer reunião permite assim a revelação de a quem se atribui em dado período o principal título do vilarejo, os títulos secundários etc. A noção de título, em suma, de nome de clã, tem valor universal, no seguinte sentido: qualquer chefe de clã pode vir a uma cerimônia envolvendo qualquer outro clã (casamento, funerais, etc.), sendo recebido em nome do "respeito" atribuído a seu título. E, em cada clã, diversos "anciãos" devem em princípio saber aproximadamente, ou ao menos de modo resumido, as fórmulas de saudações e cumprimentos que devem ser endereçadas a cada indivíduo, em função do respectivo título (se ele for chefe) ou ao qual ele está associado em virtude do seu pertencimento clânico (trata-se de vários milhares de nomes diferentes). Esse grande sistema, ao qual cada um pertence, é denominado em língua samoana o faamatai, "à moda da comunidade". Com frequência, a literatura estrangeira viu nisso o domínio de uma "elite", de uma "classe de nobres" etc., mas se trata da maneira pela qual cada habitante entende a sua identidade, em nome da qual ele pode interagir com os outros. ${ }^{18}$ Para não repetir "sistema de comunidade com chefe - mas não no sentido de um poder, de uma elite, de uma classe etc.", solicitarei ao leitor de guardar em mente a palavra "faamatai". 
Vamos intencionalmente considerar alguns dos objetos mais ocidentalocêntricos possíveis, aqueles que vêm espontaneamente à mente quando há interesse em saber "como isso ocorre nos outros lugares", com base na evidência segundo a qual esses contextos sociais são universais: a religião, a estratificação social, a propriedade, a violência e a sexualidade.

\section{A religião}

Samoa, à imagem de toda a Polinésia, é de religião cristã, desde a evangelização missionária, protestante e depois igualmente católica, no século XIX. Pois bem, nada de particular nisso, a não ser se interrogar - os trabalhos a respeito são numerosos - sobre a história dessa evangelização, a maneira pela qual os polinésios fizeram do cristianismo "a sua religião", que consideram "tradicional", e depois a chegada bem mais recente dos movimentos pentecostais, carismáticos etc. e a oposição das igrejas tradicionais a essas novidades. Constata-se, contudo, que, semanalmente, os samoanos vão à igreja, bem como que, diariamente antes da refeição da noite, uma oração em família é organizada em casa. Que colorido particular pode ter a vida religiosa? Precisamos nos reportar ao faamatai.

Tão logo se coloca a questão da interação entre o que é para nós a religião (ou prática religiosa) e o faamatai, observa-se um elemento particular (aos nossos olhos) durante a missa dominical: as dádivas feitas ao pastor do vilarejo são publicamente anunciadas e todos os futuros comentários após a missa estarão relacionados ao fato de saber se os representantes do clã Tal doaram o suficiente para "manter a sua posição" (no faamatai), relativamente aos outros clãs. O prestígio relativo entre clãs, definido igualmente em cada reunião formal dos "chefes" matai, em função dos respectivos discursos, da persuasão de Tal ou Qual em relação às opiniões dos outros no tocante a uma decisão coletiva, também se decide no contexto religioso. Uma insuficiência reiterada ("eles doaram muito pouco") pode determinar que, em dia próximo, o lugar ocupado pelo clã no vilarejo perca importância.

Essa intensa interação nos conduz então a notar que o próprio Deus, invocado pela religião local, está no início e no fim de toda a hierarquia dos títulos. Qualquer cerimônia de sucessão a um título será igualmente sancionada pelo pastor (ou padre) local, pois Deus é, de certo modo, o ápice da hierarquia dos títulos que constituem a trama mutante do faamatai. ${ }^{19}$ Essa ascendência do sistema social sobre a religião ocorre também no lar, na hora da oração sempre coletiva e organizada em torno do mais velho presente (em geral um chefe matai), que anuncia antecipadamente as "tomadas de palavra", se assim pudermos dizer, no intuito de fazer as invocações ou de iniciar ou encerrar a parte cantada (os hinos). 


\section{A estratificação social}

Outra questão, voltada para a ou as estratificações sociais, as "hierarquias", como se diz muito amiúde em sociologia; mas, para nós, é desde logo necessário precisar que a palavra é então empregada em sentido não dumontiano, devendo ser precisamente entendida como uma estratificação social. Que dizer então das hierarquias (no senso comum) entre as pessoas em Samoa? Qual seria o respectivo colorido? Se não quisermos nos ater às evidências, a esse "banal" que Mauss buscava superar, portanto, não apenas e tão simplesmente notar que um inferior tem atitudes de respeito e de obediência perante um superior, será novamente necessário nos reportarmos ao faamatai e, ao fazê-lo, provocarmos uma comparação entre formas ocidentais da estratificação e formas locais.

Já há muito tempo, eu havia tomado o contexto, não poderia haver nada de mais banal, do transporte público: os ônibus que transportam os habitantes dos vilarejos para a cidade. Cada vilarejo tem e tinha de longa data ao menos um, e com frequência vários, desses ônibus (propriedade privada de uma ou outra das famílias da localidade). Invariavelmente, há mais passageiros que lugares sentados, quer desde o início do trajeto quer após as sucessivas paradas. Constatei com espanto que ninguém ficava de pé no corredor central, a partir da ocupação total de todos os lugares, e que a única solução era ir sentar-se nos joelhos de um passageiro já sentado. A explicação não estava, ao menos principalmente, nos sacolejos ocasionados pelas estradas em mau estado. Ocorre que, no faaSamoa, manter-se em pé ao lado de pessoas sentadas é o que há de mais "deseducado", trata-se de uma provocação. A interação entre pessoas sempre deve acontecer, no contexto da vida social nos vilarejos, no transcorrer de reuniões em que todos estão sentados em círculo (em grandes "casas" abertas e redondas ou ovais), cada qual apoiado em um dos postes que formam a circunferência e cujo círculo sustenta o teto. Seja qual for o grau de calor dos debates durante a reunião, ficar subitamente em pé significa de pronto que se quer abandonar o universo da discussão para entrar na esfera do confronto físico violento. Aquele que esquecer disso, e na sua exaltação ficar em pé, será imediatamente expulso manu militari da reunião, pelos rapazes do vilarejo sentados do lado de fora (como sempre é o caso em uma reunião formal), os quais escutam e assim aprendem a arte da oratória, mas também intervêm como polícia local, caso necessário. É justamente nesse contexto cultural, sem dúvida, que um ônibus não possui nenhuma barra ou qualquer alça previstas que permitam a um passageiro nela segurar-se enquanto estiver em pé.

Outro espanto foi ver que, quando determinados passageiros subiam, os que estavam sentados na parte da frente se levantavam para lhes ceder o lugar, indo se amontoar na parte traseira sobre os joelhos de outros já sentados no fundo (e às vezes ocorria que três pessoas empilhavam-se, cada uma sentandose sobre o joelho da que se sentara primeiro). Notei que se tratava do status da 
pessoa habitante no vilarejo em questão: não de uma questão de idade ou de doença, mas sim do status, da classificação se quisermos, da pessoa que subia no ônibus (status pessoal ou status do clã ao qual a pessoa pertencia). A hierarquia do faamatai atuante no vilarejo se reproduzia ali.

Tive então a ideia de conversar com os habitantes dos vilarejos sobre o sistema de classes de transporte no transporte público das grandes cidades ocidentais, ao menos em uma época, hoje superada, em que os ônibus, e no que perdurou por mais tempo, os trens de subúrbio ou a rede de metrô, vendiam tíquetes de "primeira" e de "segunda" classe, os primeiros dando acesso às áreas cujos lugares estavam com frequência disponíveis (e com assento mais confortáveis). Alguns dos meus interlocutores, em razão de sua experiência de trabalho no exterior (Nova Zelândia, EUA etc.) entendiam perfeitamente a que eu me referia, podendo comparar com algo que conheciam de perto, em virtude das suas viagens ultramarinas: o sistema de classe dos transportes aéreos. Fiz então a proposta, que não imaginara ser tão provocadora, de instituir tal sistema nos ônibus de Samoa ou, ainda, tal como é o caso nas grandes cidades de Fiji, de ônibus com trajetos diretos, lugares sentados garantidos, mas com tarifa bem mais alta, além dos micro-ônibus, sem lugares sentados e com tarifas baixas. A reação foi imediata e unânime (levantei a discussão com inúmeras pessoas diferentes, em diversos vilarejos): "seria escandaloso, totalmente anti faaSamoa, os ônibus de uma família ou empresa que ousassem introduzir tal distinção seriam queimados etc.". ${ }^{20}$

Sucederam-se longas discussões comparativas e, a meu ver, um exemplo pedagógico privilegiado para mostrar como a hierarquia na sociedade samoana, aquela ligada ao faamatai, não tem nada a ver com o que nós denominamos com essa palavra e que precisaríamos encontrar meios de distinguir, pouco importando por qual vocabulário, as duas "hierarquias". Segui Louis Dumont que, há muito tempo, tinha sentido a necessidade na Índia de distinguir as diferenças "de casta" e as outras estratificações associadas ao poder territorial, à economia moderna etc. e que, desde os anos I960 in loco, distinguiu fortemente a "estratificação social", no sentido recorrente da sociologia anglo-americana, e o que ele denominou "hierarquia", dando a esse termo o sentido especializado que conhecemos.

\section{A relação de propriedade}

Outro exemplo que aparenta ser universalista a priori: a noção de propriedade, de bem possuído. Qual é a atitude dos samoanos nesse âmbito? Poderíamos escrever páginas sobre o fato de que, em uma sociedade em que a ênfase no coletivo é acentuada a tal ponto (o sistema matai e todas as suas regras), a veemência das eventuais discussões sobre a posse ("isto é meu!") pode ser bem considerável. Aqui, novamente nada além do banal, ao menos para aqueles que não cometem o erro de acreditar que, em sociedades que pretendemos quali- 
ficar como holísticas, não seria possível encontrar comportamentos acentuadamente "individualistas" (com o erro de misturar uma tipologia exógena de ideologias e um método sociológico - já discutimos esta noção de holismo: ideologia ou método sociológico?). O que é menos banal é ver o que acontece se confrontarmos sistematicamente ao faamatai as ocorrências em termos de expressão e prática do "isto é meu!".

Em quais casos a expressão da propriedade interage com o faamatai e quando ela não o faz? Por falta de espaço não me alongarei no ponto e passaremos à conclusão. Há uma grande lista de bens possuídos cuja posse não interage com o faamatai, a tal ponto, que isso deixa de causar espanto. Nesse universo social em que os laços de parentesco ampliado são tão fortes, em que as obrigações de ajuda mútua etc. são tão pronunciadas, sustentadas pela noção de alofa (empatia), e que unem todos aqueles aparentados no seio do clã, uma pessoa não hesitaria em solicitar compensação (dinheiro, troca) a seu primo antes de lhe emprestar um objeto útil, geralmente comprado na cidade, eventualmente industrializado, todos tendo algo em comum, que responde à seguinte definição: o possuidor (aquele que diz "isto é meu!") está na base da relação de posse. Não se trata apenas de objetos "modernos", também podem estar incluídos produtos tradicionais e cerimoniais (esteiras finas, alimentos), mas que não são dados no contexto de uma troca cerimonial de dádivas codificadas. ${ }^{21}$ Nesses contextos de empréstimo com compensação, aparentemente estamos bem longe do faamatai. No que tange a outros bens, não causa espanto que sua disponibilização seja ou impossível ou muito regulamentada pelo faamatai: "minha terra", "minha casa" e, bem entendido, relações como "meu título de chefe", "meus país" etc. Trata-se, nesse caso, de bens em cuja origem da posse o possuidor não está.

A distinção entre as duas categorias é destacada na língua (dois sistemas lexicais de adjetivos possessivos) e por expressões, com frequência notadas na Oceania: "não sou eu que possuo a minha terra, é ela que me possui", "nós somos os filhos da terra" etc.

A distinção é evidente, quase banal, dir-se-ia: os bens pessoais e os bens socialmente valorados, mas essa comparação com o faamatai desemboca em uma constatação mais específica. Não se trata, por exemplo, de uma distinção entre bens coletivos e bens individuais, mas de uma questão de origem: estou ou não na origem da posse do objeto relativamente ao qual digo "isto é meu!". Esse é o colorido particular da posse em Samoa.

\section{A violência}

Outro exemplo, desde logo e uma vez mais universal: a violência. Nenhuma sociedade na Terra dela escapa, todos sabemos. O que então dizer de específico a seu respeito? Listar as ocorrências que levam a que um desentendimento se torne um enfrentamento físico, eventualmente mortal, não confere qualquer 
colorido muito particular. Outra pista é mais esclarecedora: observar a relação com o faamatai e, mais precisamente, perguntar aos samoanos o que eles pensam acerca da relação entre o seu sistema social, por eles constantemente discutido, esse famoso faamatai, e o fato de que um desentendimento entre indivíduos pode bem rapidamente provocar graves ferimentos.

A resposta que, para mim, foi uma forma de caracterizar o colorido da violência, consistiu no seguinte: "não há qualquer relação! Mesmo quando um observador externo, atento em buscar a origem da desavença que foi capaz de provocar golpes físicos, estiver convencido de encontrar algo referente a questões de status ("ele se atreveu a falar antes de mim, sentar-se no lugar que me cabe", "ele me humilhou diante do meu chefe de clã"), ou de propriedade ("ele pegou sem autorização o que era meu") etc., ocorre que, se a desavença acaba em luta corporal, a explicação da raiva que a levou a não se conter, a passar da palavra às vias de fato, está sistematicamente desligada de tudo o que poderia se relacionar à vida social. "Não temos culpa nisso", "é o Diabo que assume o controle"; e o interlocutor se enraivece ou considera com desprezo ou pena o seu interlocutor - o observador estrangeiro que "decididamente não entende nada do faaSamoa" - se este último se obstinar a invocar uma origem ligada a uma relação social qualquer. Sim, a origem social de um desacordo é evidentemente reconhecida. Mas o fato que ter ocorrido uma posterior violência não o é. Há uma espécie de rejeição em massa - uma denegação, dirão alguns contra qualquer evocação de eventual laço, como se o fato fosse um sacrilégio.

Nesse âmbito, um debate antropológico tornou-se um estudo de caso. Um jovem antropólogo americano publicou um estudo sobre a organização social em Samoa (Shore, I982), usando como fio condutor um evento local: a morte de um chefe por outro. As circunstâncias poderiam sugerir um infeliz acaso: jogo de baralho, jogadores embriagados, acusações de trapaça, o acusado tirado do sério e louco de raiva que se levanta, vai até a sua casa, logo ao lado, volta com um fuzil e atira naquele que o agredia verbalmente. O antropólogo quis identificar o episódio, certamente imprevisto, como resultante de uma tensão longamente acumulada entre dois clãs, com histórias de títulos e de terras, o que lhe rendeu uma boa introdução para sua análise global da estrutura social. A reação de vários samoanos, dentre os quais professores que intervieram em publicações acadêmicas, foi acusar o antropólogo de não ter entendido nada dessa sociedade, a ponto de ser capaz de formular a hipótese, totalmente incongruente (a seus olhos), de que uma violência pudesse ser explicada pelo sistema social, ainda que indiretamente. ${ }^{22}$

Aqui novamente, a partir desse colorido particular assumido pela violência e seguindo o fio dessa meada, o observador pode avançar sobremaneira na compreensão comparativa da sociedade. A visão samoana faz do mundo social um lugar posicionado sob a luz (divina e solar), em que todos os laços são organizados pelo faamatai, no mais amplo sentido, estando esse mundo social, o 
vilarejo no sentido de comunidade, sempre rodeado de um exterior, uma "selva" de certo modo (o espaço entre vilarejos, a direção rumo ao interior da ilha ou, no outro sentido, rumo ao alto-mar, tão logo ultrapassada a lagoa que, por sua vez, pertence ao "interior"). Trata-se igualmente da diferença de localização entre Deus e "os espíritos" (ou o Diabo, noções próximas). Justamente nesse exterior incontrolável situa-se a violência que, eventualmente, irrompe no interior e que sempre se deve tentar interromper, o quanto antes, sob pena de o exterior, sombrio e submetido a forças "diabólicas", se amparar no interior luminoso e ordenado, o que equivaleria ao fim da "sociedade", o fim do faaSamoa.

\section{A sexualidade}

Esse esclarecimento trazido pelo colorido singular que assume a violência na sociedade samoana presta-se ainda à percepção do colorido samoano desta outra atividade humana universal: a sexualidade, último exemplo por nós aqui abordado. Nada de muito particular em Samoa, em comparação com tantas outras sociedades, na Oceania ou alhures, no que tange à prática da sexualidade, e tampouco acerca da grande desigualdade relativa às proibições que pesam sobre rapazes e garotas. Notemos apenas, no tocante às evidentes particularidades para a observação e seja qual for o método, que a noção missionária do pecado da carne não fincou, de forma alguma, raízes em solo samoano. Se acrescentarmos a ausência completa de toda e qualquer ideia de mutilação sexual feminina, compreenderemos que o reconhecimento da existência do prazer, até mesmo para os dois sexos, não é barrada por outras considerações.

Mas nem pensar em falar a respeito! Com efeito, o que é bem mais inesperado, sobretudo após a observação que acabamos de fazer, é a quase impossibilidade para o visitante de simplesmente falar sobre sexualidade com seus hóspedes samoanos, seja em uma conversa com várias pessoas ou até mesmo a dois. “Não, não se deve falar disso!” E, no entanto, nada a ver com o que seria uma capa de pudor herdada da época missionária, visto que, em que pesem meus esforços para fazer com que se evocasse qualquer laço entre o ato sexual (o "fazer" em samoano) e a "vergonha", no sentido mais geral (noção bem conhecida e constantemente evocada: $\mathrm{ma}$ ), meus interlocutores respondiam com a negativa. Mais uma vez, porém, as coisas se esclarecem bem melhor se compararmos a sexualidade (representações da prática) com o faamatai. Tanto quanto cada um é livre para fazer o que quiser (e, para ser sucinto, com quem ele quiser e que consinta) fora da área do vilarejo, portanto, na "selva", o fato de mencionar a "coisa" no vilarejo, ou de evocá-la com gestos, é bem mais que inconveniente. A tal ponto que, na vida pública da comunidade, o observador que se limitasse a anotar manifestações de carinho teria dificuldade em saber se a dupla observada se compunha de dois cônjuges ou de dois parentes, até porque ele não observaria nenhum gesto de carinho nos dois casos. Mais uma vez, avançando nos diálogos verbais, na análise do vocabulário, das atitudes etc. 
(Tcherkézoff, 2003: 277-442), acabamos por notar uma configuração das representações, a um só tempo, muito particular e inesperada.

Desde o início das minhas estadas em Samoa (I98I), anotei uma série de observações que me surpreendiam e que acabaram por compor um todo coerente, ainda que muito singular. Por um lado, nos vilarejos e no seio das famílias em que fui acolhido, a totalidade das conversas, das atitudes, dos termos de parentesco, em sutileza e em referência, pareciam se limitar a um mundo de "famílias" aiga, em que o lugar de cada um era determinado por uma genealogia, portanto, por caminhos de parentesco (laços que nós, ocidentais, dizemos ser "de sangue"), e não por laços de casamento, de aliança entre clãs, de política matrimonial. Cada qual era um "herdeiro", uma criança "da terra". Levei algum tempo para distinguir aqueles que estavam lá na qualidade de "cônjuges" (sempre "vindos de outro lugar"). Nesse mundo, todas as preocupações aparentemente se voltavam para o que se pode dizer ou omitir, acerca da maneira pela qual se portar em uma reunião, para o registro de vocabulário possível, ou estavam relacionadas ao posto, ao status, justificado por memórias genealógicas. As questões que me importavam, referentes ao que se espera socialmente de um "homem" ou de uma "mulher", não encontravam resposta, salvo nessa esfera em que os dois sexos são irmãos e irmãs, tios e tias etc., jamais marido e mulher. Quanto à sexualidade, ao que era possível se esperar dela, sobre o que era tolerado ou não, sobre as categorias que podiam ou não nutrir uma relação sexual, minhas questões caíam no vazio ou pareciam deslocadas. Falava-se de tudo, com exceção de... sexualidade.

Posteriormente, em conversas que jamais ocorriam em grupo, mas apenas com um único interlocutor (ou mais raramente uma interlocutora), assuntos ligados a práticas, obrigações, proibições etc., e relativos à sexualidade puderam ser abordados. Tive a curiosa impressão de entrar em outro universo; abandonando um mundo dominado por uma etiqueta muito estrita, com profusão de regras, para entrar em um universo que parecia, a um só tempo, muito livre, mas onde cada um era, por assim dizer, um indivíduo solitário. Deixava-se igualmente para trás um mundo de relações de parentesco para se adentrar em um campo onde não havia nada a não ser "homens" (tamaloa, tane) e mulheres (fafine), interligados por uma única modalidade possível de relação. E ainda, essa ideia de "relação" sexual que temos não era mais absolutamente uma "relação" no sentido samoano da noção (a palavra samoana va, noção muito valorizada), mas um mundo de "atos", em que cada um "faz", muito mais que "está em relação", um mundo de relações heterossexuais entre homensmachos e mulheres-fêmeas.

Uma grande consequência sobre a análise do gênero na sociedade de Samoa. Não há dois "gêneros", dois perfis do que, por um lado, o "homem" ou o "masculino" são ou devam ser e, por outra parte, o que a "mulher" ou o "feminino" são ou devam ser. Há dois mundos de relações, dois níveis no interior 
da ideologia global. No primeiro mundo, cada qual é como um irmão para uma irmã ou uma irmã para um irmão. Esse mundo é aquele do visível, da "luz" (noção a um só tempo física, cosmológica e bíblica). No outro mundo, o reino humano (tagata) é feito como o reino animal (manu). Cada qual é uma "criatura viva" mea ola, tendo como única distinção a diferença dos sexos, uma diferença que não intervém a não ser em uma única relação: a relação heterossexual. É um mundo do sexuado-sexual: o primeiro termo implica o segundo e é nisso que reside uma grande diferença com relação à visão ocidental contemporânea da diferença dos sexos. Lá, humanos e animais se encontram. Trata-se do mundo das "criaturas" (todas criadas por Deus), em que humanos e animais, sendo "criaturas vivas" mea ola, são naturalmente machos/fêmeas e, portanto, destinadas a se acasalarem. Por outro lado, realmente do outro lado da barreira, retomamos o primeiro nível evocado: o mundo da comunidade do vilarejo nuu com, pouco ou amplamente, o universo de todo o "costume" (aga-nuu: literalmente: "a essência do fato de viver em comunidade"), em que cada qual é como um irmão para uma irmã ou uma irmã para um irmão.

Essa dicotomia de referências e de definições do pertencimento individual é fundamental na cultura samoana: ${ }^{23}$ por um lado o vilarejo, como círculo sagrado de nomes ancestrais, por outro, um mundo sexuado-sexual. No primeiro mundo, a classificação é complexa e a referência ao ato sexual não é organizadora do conjunto. No segundo, são macho/fêmea, em relação ao ato heterossexual. Tudo isso possibilita-nos ver o colorido da sexualidade em Samoa. Primeiro traço desse colorido: o universo da sexualidade começa onde a sociedade (a vida em comunidade) cessa. Trazer essa dimensão para a sociedade é justamente o que envergonha: rumores de relações antes do casamento, por exemplo; mas igualmente os gestos, mesmo aqueles mais simples, mas feitos em público, entre cônjuges. Tudo isso evoca o fato da existência do laço sexual entre nós e abre, subitamente, a suspeita acerca do zelo de cada um pelo rumo da comunidade, em que a esfera "privada" não deve intervir. Outra consequência particular: a quase impossibilidade, em todo caso na comunidade do vilarejo, de uma amizade, no sentido ocidental entre pessoas de sexo diferente. Aos olhos dos outros, ou se é parente ou parceiro em potencial, mesmo que os interessados estejam a mil léguas de pensar em tal parceria. A suspeita de relações reais, mas às escondidas, é muito rapidamente criada se duas pessoas de sexo diferente, adolescentes ou não, se frequentarem abertamente, pois a amizade sem segundas intenções é praticamente impensável. Tudo isso está no cerne da vida do vilarejo que gera uma imagem muito forte de uma grande parentela, em que cada um é, pelo menos à luz do dia (portanto, em público, no "visível”, na "luz"), “como irmão e irmã" (Tcherkézoff, 20I7).

Outra consequência: somente a heterossexualidade é pensável. Em razão de a sexualidade estar unicamente no mundo das "criaturas vivas", digamos, existir com base no modelo animal, o que o mundo ocidental ou global chama "homos- 
sexualidade" torna-se impensável. Segue, uma vez mais, uma situação muito particular para os indivíduos que são, digamos, "transgênicos" e que, em outros universos culturais, seriam talvez homossexuais (Tcherkézoff, 20I4). O laço homossexual entre mulheres é totalmente barrado, trata-se de "uma coisa dos $\mathrm{Pa}$ palagi", dos europeus, é algo "impensável aqui" (e o único meio para mulheres viverem essa vida, e ainda com dificuldade, consiste em emigrar). Quanto a este tipo de laço entre homens, ele existe, mas na forma muito particular de rapazes ou homens "afeminados", reputados por somente procurarem como parceiros sexuais homens hétero normativos, com os quais eles desempenham papel de uma mulher (daí deriva a sua denominação em língua local: "como mulheres" faafafine). Esses afeminados, tal como o povo em geral, explicam ao visitante que eles "não são gays", que "a homossexualidade não existe em Samoa" e, de fato, em Samoa, nenhum desejo de relações íntimas viria à mente de um afeminado em virtude de atração por outro afeminado. Não se trata aqui de decidir se há ou não "homossexualidade" em Samoa, como um bom ocidental levado pelo seu olhar estrangeiro que esquece que a noção de orientação sexual é uma invenção inteiramente ocidental e bem datada, como nos relembra Foucault. Interessa-me aqui o fato de que o método seguido possibilita compreender por que, no discurso dos samoanos que residiram no exterior, a homossexualidade "não existe aqui". O colorido da sexualidade samoana, ou seja, aquilo que a torna totalmente adstrita ao universo pensável do que denominamos heterossexualidade, torna o que nós denominamos homossexualidade "estranho".

Por fim, outro ensinamento proporcionado por esse esclarecimento da tonalidade específica da sexualidade: uma compreensão do imenso mal-entendido criado pelo famoso livro L'adolescence à Samoa, de Margaret Mead (I928 para a primeira publicação em inglês, I963 para a tradução em francês). Em função de suas leituras (dos antigos viajantes vindos até a Polinésia, desde Bougainville), de sua educação universitária (as aulas sobre a Polinésia ensinavam que a cultura polinésia colocava a sexualidade no centro das preocupações para todos os habitantes), assim como de seu projeto de trabalho (provar que o universo da sexualidade é regido, ao menos em parte, pela cultura e não somente pela natureza biológica do corpo humano), Mead havia chegado a compor um quadro em que os jovens samoanos estariam inteiramente livres dos problemas e tensões da "crise da adolescência". De acordo com ela, a educação oferecida a eles por sua sociedade favoreceria "o amor livre", pois, de modo mais geral, a estrutura social global da sociedade havia desenvolvido pouquíssimas proibições no cotidiano ("salvo para as poucas filhas de chefe"). Bem mais tarde, outros, que conheciam a sociedade samoana em maior profundidade por terem lá vivido em anos próximos ou posteriores, tomariam a palavra. Intelectuais samoanos juntaram-se a estes últimos. Os mais antigos insistiram no erro fundamental das interpretações de Mead, e os demais - e é isso o que aqui nos interessa - gritaram, escandalizados, e denunciaram um livro que, segundo os pró- 
prios termos, apresentava a sociedade samoana como uma "promiscuidade à moda dos animais".

Quantos mal-entendidos! Uma parcela dos partidários de Mead acreditou de boa-fé que os protestos samoanos decorriam de um universo de hipocrisia resultante da obra pregressa dos missionários. Quando, em verdade, os samoanos protestavam porque se rebelavam contra o que entendiam como uma superposição entre o universo da sexualidade "das criaturas vivas" e os seus valores culturais, a sua sociedade e as suas comunidades aldeãs. Com efeito, Mead havia cometido o erro de acreditar: I) em uma grande permissividade da sociedade e; 2) que isso resultava do pano de fundo cultural samoano - e, de resto, "polinésio". O erro profundo de Mead acerca desse pano de fundo cultural, que se uniu sem dúvida àquele de todos os antigos viajantes que estiveram na Polinésia, foi o de entender como "valores culturais" a atmosfera de "despreocupação" [casualness] (foi essa a sua expressão) da sexualidade em relação à sociedade e a suas regras, como se se tratasse de um valor (no sentido dumontiano) da sociedade/cultura samoana; como se o visitante estrangeiro acreditasse ser a "liberdade sexual" uma escolha da sociedade, ao passo que essa atmosfera de "liberdade" era inteiramente outra coisa: tratava-se de uma não significação, de uma exterioridade com relação ao social, de um estar fora do mundo (social) e, em especial, de uma "liberdade da solidão", tal como tive a oportunidade de explicar reiteradas vezes. ${ }^{24}$

Espero que me perdoem pelo extremo resumo dos poucos exemplos apresentados, considerando o espaço limitado a um artigo e o fato de as publicações estarem disponíveis ao leitor para o aprofundamento de cada exemplo. Ainda assim, espero, entretanto, que essas poucas evocações tenham possibilitado conferir algum conteúdo à noção do método holístico, a parte " $R$ " da fórmula dumontiana "O = I + R" ou, como prefiro amplamente, o "colorido" específico do fato social, de acordo com o vocabulário de Mauss, muito distante do universal banal que o Mestre denunciava no método de seus contemporâneos.

Recebido em I9/05/20I7 | Aceito em 20/06/20I7

Tradução de Luís Hernan de Almeida Prado Mendoza Revisão técnica de Maria Laura Cavalcanti

Serge Tcherkézoff é professor de antropologia, diretor de estudos na École des Hautes Études en Sciences Sociales (EHESS), membro do Centre de Recherche et de Documentation sur l'Océanie (Credo) e autor de, entre outros livros, FaaSamoa, une identité polynésienne: L'anthropologie comme dialogue culturel (2003). 


\section{NOTAS}

I Comunicação pessoal, de aproximadamente I978, que cito de memória.

2 Ele já se manifestara nesse sentido em textos de I960, mas tais propósitos não se tornariam conhecidos para além do círculo dos indianistas, a não ser após sua retomada em Homo Hierarchicus (ver os "Apêndices").

3 Segundo minhas lembranças, ao menos uma vez, Daniel de Coppet evocou diante de mim suas conversas com Dumont sobre esses temas.

4 Em seus Essais sur l'individualisme (1983: cap. 4). Ver também de Lara (2008, 20II). Igualmente no tocante a essa questão, o aspecto metodológico de Dumont foi às vezes mal compreendido e levou a uma história das ideologias (Bensa, 2008).

5 Mesmo que esse nível seja da ordem da "plausibilidade" e não da "falseabilidade"; ver Olivier de Sardan (I996, 2004). De fato, é essencial: I) admitir, juntamente com Passeron (I99I) e muitos outros, que as ciências sociais são apenas interpretativas; porém 2) recusar fortemente o tema pósmoderno e niilista segundo o qual todas as interpretações se equivalem (o relativismo absoluto tem apenas um único destino: a rejeição do outro e, certamente, não resulta em uma melhor compreensão de sua diferença).

6 No que diz respeito a Mauss, trata-se a um só tempo de uma escolha e de uma questão de época. O fato "social" contempla tudo (ações e relações) o que é "obrigatório" em virtude da vida "em grupo". Essa "escola sociológica" se distingue da anthropology, como da antropologia das religiões, então representada por Frazer, Jevons, Tyler etc., os quais buscavam diretamente os universais do pensamento religioso, as leis intelectuais do raciocínio "primitivo". A "antropologia" francesa, por sua vez, antes de Mauss, esteve por muito tempo limitada ao que atualmente se denomina antropologia física e, quando Mauss utiliza o termo, o faz para os comportamentos que lhe parecem derivar, a um só tempo, da fisiologia e do social, tal como a maneira pela qual o pensamento social sobrecarrega de significações a natural assimetria entre a direita e a esquerda (Tcherkézoff, 2016: 46, 64-67, II 2-II4). 
7 Ou "Unidade do Homem e diversidade das culturas", como por muito tempo se manteve a bela designação da seção de antropologia do comitê nacional do CNRS (a seção "38"). Disponível em <http://www.cnrs.fr/comitenational/doc/ rapport/2004/rapport/sections/0823-0836-Chap38.pdf $\geq$. Esse relatório apresentado por Gérard Toffin, então presidente dessa seção, contém uma discussão metodológica acerca da disciplina e um balanço da antropologia francesa da época.

8 Ver Dumont (1983: I9I e I74); para as citações de Mauss, ver Dumont (I966: 324n).

9 Lévi-Strauss utilizou (abusou de) essa distinção para tentar triar, no Essai sur le don, de Mauss, o que derivaria de um primeiro Mauss, demasiado preocupado em parafrasear as crenças indígenas sobre a circulação das dádivas (um "espírito" nas coisas dadas), e um segundo Mauss, de certo modo pré-estruturalista, que teria considerado o caráter universal da reciprocidade um dado fundador da condição humana. Para uma crítica da crítica lévi-straussiana de Mauss, ver Tcherkézoff (2016: 84-92, I49-175).

Io Redesenhamos mais de perto essa genealogia dos conceitos (Tcherkézoff 2016: 29-43, 95-123).

I I Ver Tcherkézoff (I983, I985, I986, I992, I993b, I994b, I995a, I996).

I2 Ver Dumont (I978, I979 posfácio, I983: 218-9).

I3 Ver Tcherkézoff (I995b, I998, 2003: conclusão, 2004, 2005a, b).

I4 Salvo um relatório científico, parcialmente inédito: "La comparaison anthropologique: une traduction holiste sans grand partage" [A comparação antropológica: uma tradução holística sem grande divisor]. Esse relatório de várias centenas de páginas foi entregue ao Ministério do Ensino Superior e da Pesquisa em fevereiro de 1995 e publicado, no mesmo ano, em Les régimes de scientificité de l'anthropologie en France. Essai de synthèse et Documents à l'appui (eds. Michel Izard e Gérard Lenclud. Paris: APRAS, p. 299-327). A parte "documentos de apoio" continuou inédita; apenas a introdução, assinada pelos dois coordenadores, de 70 páginas, foi publicada com o mesmo título nessa edição.

I5 Povo do norte da Índia. [N. T.] 
I6 E, de passagem, esqueçamos a escolha um tanto quanto infeliz do termo dumontiano "residual", que pode levar a crer que o fato empírico do poder, nestas circunstâncias, seja menos importante, sociologicamente falando, do que a ideologia, a "religião" etc. Com certeza Dumont havia imediatamente tentado precaver-se contra essa falsa interpretação: "componente... que chamaremos residual sem pressuposto ontológico", denominado assim tão somente "para assinalar a maneira pela qual ele é colocado em evidência”. Contudo, é imperativo reler atentamente esse trecho para notá-lo e dele se lembrar.

I7 Uma vez mais, por falta de espaço, só nos é dado fazer referência às publicações (Tcherkézoff, 2003: Posfácio; 2008; 2015).

I8 Dediquei numerosas páginas à discussão desse profundo mal-entendido concernente à análise socioantropológica ocidental (ver Tcherkézoff, 2003: 177-274; 2008: 255-263, 285-292; 2017).

I9 Para mais detalhes, ver Tcherkézoff, 2008: 266-276.

20 Para mais detalhes, ver Tcherkézoff, 2003: I77-210 (uma versão mais curta foi publicada em r995b).

2I Para o estudo das dádivas cerimoniais em Samoa, ver Tcherkézoff (2016: II parte).

22 Para os detalhes do debate e o ensinamento a extrair em prol de uma antropologia da violência em Samoa, ver Tcherkézoff (2003: 459-473).

23 No transcorrer do período histórico que pudemos estudar: do final do século XIX até os anos I980-I99o. Evidentemente, não se trata de dizer que haja "uma cultura samoana" eterna (para esse debate, ver Tcherkézoff, 2003: Posfácio, e 2015).

24 Tcherkézoff (200I: cap. I; 2003: cap. 9; 2010: cap. I6). 


\section{REFERÊNCIAS BIBLIOGRÁFICAS}

Bensa, Alban. (2008). Louis Dumont et le totalitarisme, Annales, 2, p. 377-38I.

Dumont, Louis. (I99I). Homo Aequalis (II). L'idéologie allemande, France-Allemagne et retour. Paris: Gallimard (Bibliothèque des sciences humaines).

Dumont, Louis. (1983). Essais sur l'individualisme. Une perspective anthropologique sur l'idéologie moderne. Paris: Seuil (Esprit).

Dumont, Louis. (I979). Prefácio \& Posfácio. In: Homo hierarchicus. [Reedição.] Paris: Gallimard (Tel).

Dumont, Louis. (1978). La communauté anthropologique et l'idéologie. L'Homme, I8/3-4, p.83-ı ıo.

Dumont, Louis. (I97I). Introduction à deux théories d'anthropologie sociale. La Haye: Mouton.

Dumont, Louis. (1966). Homo Hierarchicus. Paris: Gallimard (Bibliothèque des sciences humaines).

Héritier, Françoise. (1992). Sur la comparaison. Actes des Journées de l'EHESS. Paris, 4 [inédito].

Lara, Philippe de (ed.). (20II). Naissances du totalitarisme. Paris: Ed. du Cerf.

Lara, Philippe de. (2008). Anthropologie du totalitarisme. Lectures de Vincent Descombes et Louis Dumont, Annales, 2, p. 353-375.

Lévi-Strauss, Claude. (I988). De près et de loin (Entretien avec Didier Eribon). Paris: Odile Jacob.

Lévi-Strauss, Claude. (1962). La pensée sauvage. Paris: Plon. Mauss, Marcel. (I968). Mauss, Euvres [regroupées et présentées par Victor Karady]. Paris: Les Éditions de Minuit. Mead, Margaret. (1963). Mœurs et sexualité en Océanie. Paris: Plon (Terre humaine).

Mead, Margaret. (1928). Coming of Age in Samoa. New York: Morrow.

Olivier de Sardan, Jean-Pierre. (2004). La rigueur du qualitatif. L'anthropologie comme science empirique. Espaces Temps, 84/I, p. 38-50.

Olivier de Sardan, Jean-Pierre. (I996). La violence faite aux données: de quelques figures de la surinterprétation 
en anthropologie. Enquête, 3I/59. Disponível em <https:// enquete.revues.org/363>. Acesso em I5 nov. 2017 Passeron, Jean-Claude. (I99I). Le raisonnement sociologique. L'espace non-popperien du raisonnement naturel. Paris: Nathan.

Tcherkézoff, Serge. (2017). The Samoan Village, the Brother-Sister Relationship and the Rule of Exogamy. Journal of Samoan Studies, 7/2, p. 6-36.

Tcherkézoff, Serge. (2016). Marcel Mauss à Samoa: le holisme sociologique et le don polynésien. Marselha: Pacific-Credo Publications.

Tcherkézoff, Serge. (20I5). La culture sans essentialisme: l'exemple d'un "droit coutumier" dans la société multiculturelle de la Nouvelle-Calédonie. Le Débat, I86/4, p. 8I-93.

Tcherkézoff, Serge. (2014). Transgender in Samoa: the cultural production of gender inequality. In: Niko Besnier \& Kalissa Alexeyeff (eds.). Gender on the edge: transgender, gay and other Pacific Islanders. Honolulu: University of Hawaii Press, p. II5-I34.

Tcherkézoff, Serge. (2010) [2004]. Tahiti I768, jeune filles en pleurs. La face cachée des premiers contacts et la naissance du mythe occidental. Papeete: Au Vent des Iles.

Tcherkézoff, Serge. (2008). The changing South Pacific: identities and transformations. Canberra: Australian National University Press. Disponível em <http://epress.anu. edu.au/changing_south_pacific_citation.html>. Acesso em I5 nov. 2017.

Tcherkézoff, Serge. (2005a). Aux prises avec des hiérarchies qui ne sont pas des inégalités: exemples polynésiens (Samoa). In: Leservoisier, Olivier (ed.). Terrains ethnographiques et hiérarchies sociales: retour réflexif sur la situation d'enquête. Paris: Karthala, p. 285-308. (Hommes et sociétés).

Tcherkézoff, Serge. (2005b). Occident-Polynésie et retour: navigations dans l'espace-temps. In: Rigo, Bernard (ed.). L'espace-temps en Polynésie. Papeete: Isepp/Au Vent des Iles, p. I07-I34 (Cahiers du Larsh, 2).

Tcherkézoff, Serge. (2004). Visions européennes et polynésiennes de l'espace-temps insulaire du XVIIIe siècle à 
nos jours. In: Dunis, Serge (ed.). Le Grand Océan: le temps et l'espace du Pacifique. Genebra: Georg, p. 277-302.

Tcherkézoff, Serge. (2003). FaaSamoa, une identité polynésienne (économie, politique, sexualité). L'anthropologie comme dialogue culturel. Paris: L'Harmattan (Connaissance des hommes).

Tcherkézoff, Serge. (200I). Le mythe occidental de la sexualité polynésienne: Margaret Mead, Derek Freeman et "Samoa". Paris: PUF (Ethnologies).

Tcherkézoff, Serge. (I998). Mua/Muri: ordre, espace et temps en Polynésie. Le cas samoan comparé au tahitien et le rapport à l'Occident. Bulletin de la Société des Etudes Océaniennes, 276, p. 27-5I.

Tcherkézoff, Serge. (I996). Les oppositions dualistes "droite/gauche", la politique française et l'anthropologie des classifications. Gradhiva, 20, p. 67-8I.

Tcherkézoff, Serge. (I995a). La totalité durkheimienne (E. Durkheim et R. Hertz): un modèle holiste du rapport sacré/profane. L'Ethnographie, 9I/I (Regards actuels sur Durkheim et sur Mauss), p. 53-69.

Tcherkézoff, Serge. (I995b). L'autocar à Samoa ou la hiérarchie au quotidien. Gradhiva, I8, p. 47-56.

Tcherkézoff, Serge. (I994a). L'inclusion du contraire (L. Dumont), la hiérarchie enchevêtrée (J. P. Dupuy) et le rapport sacré/pouvoir. Relectures et révision des modèles à propos de l'Inde. [2 partes]. Culture, I4/2, p. II3-I34; I5/I, p. 33-48.

Tcherkézoff, Serge. (I994b). Hierarchical Reversal, ten years on (Africa, India, Polynesia). [2 partes]. Journal of Anthropological Society of Oxford, 25/2, p. I33-I67; 25/3, p. 229-253.

Tcherkézoff, Serge. (I993a). L'individualisme' chez Louis Dumont et l'anthropologie des idéologies globales: genèse du point de vue comparatif. [2 partes]. Anthropologie et Sociétés, I7/3, p. I4I-I58; I8/I, p. 203-222.

Tcherkézoff, Serge. (1993b). La relation roi/prêtre en Inde selon Louis Dumont et le modèle de l'inversion hiérarchique. Gradhiva, I4, p. 65-85. 
LOUIS DUMONT, A COMPARAÇÃO DAS SOCIEDADES E O DIÁLOGO CULTURAL

Tcherkézoff, Serge. (I992). La question du 'genre' à Samoa. De l'illusion dualiste à la hiérarchie des niveaux. Anthropologie et Sociétés, I6/2, p. 9I-II7.

Tcherkézoff, Serge. (I986). Logique rituelle, logique du tout. L'exemple des jumeaux nyamwezi. L'Homme, Iоo, 26/4, P. 9I-II7.

Tcherkézoff, Serge. (1985). Black and white dual classification: hierarchy and ritual logic in nyamwezi ideology. In: Barnes, Robert Harrison; Coppet, Daniel de \& Parkin, R.J. (eds.). Contexts and levels. Anthropological essays on hierarchy. Oxford: J.A.S.O., p. 54-67 (Occasional papers, 4).

Tcherkézoff, Serge. (1983). Le roi nyamwezi, la droite et la gauche. Révision comparative des classifications dualistes. Paris/Cambridge: Maison des Sciences de l'Homme Press/ Cambridge University Press. 
Palavras-chave

Totalidade (social);

hierarquia;

holismo metodoló-

gico;

Louis Dumont;

Marcel Mauss.
Keywords

Totality (social);

hierarchy;

methodological holism;

Louis Dumont;

Marcel Mauss.

\section{LOUIS DUMONT, A COMPARAÇÃO DAS} SOCIEDADES E O DIÁLOGO CULTURAL

Resumo

O artigo é um chamado à releitura de Louis Dumont, destinado a todos os antropólogos, quaisquer que sejam suas áreas de estudos. Trata-se de reconhecer toda a importância do método holístico geral proposto por Dumont para a disciplina sociológica-antropológica. São abordadas as seguintes questões: a necessidade de distinguir o holismo metodológico aplicável ao estudo de todas as sociedades da tentação de fazer uma grande divisão entre sociedades que seriam holísticas e outras que não o seriam; os laços históricos entre Louis Dumont e os estudos das sociedades da Oceania; a dualidade inerente à observação que reflete a posição do antropólogo e conduz a distinguir o que Dumont denominava, com vocabulário não tão apropriado, a ideologia e o "resíduo". Ao final do percurso, são apresentados exemplos relativos à sociedade polinésia de Samoa, os quais vêm ilustrar os argumentos de método desenvolvidos no artigo.

\section{LOUIS DUMONT, THE COMPARISON OF SOCIETIES AND THE CULTURAL DIALOGUE}

\section{Abstract}

This article is a call to reread Louis Dumont, adressed to all anthropologists, whatever their area of study. Its aim is to reaffirm the importance of the general holistic method proposed by Dumont for the discipline of sociology-anthropology. The following issues are broached: the need to distinguish a methodological holism which can be applied to the study of all societies from the temptation to establish a great divide between those societies that might be classed as "holistic" from those that might not; the historical links between Louis Dumont and the study of Oceanic societies; the dualism inherent to the observation that reflects the position of the anthropologist and leads to the distinction that Dumont called (with a somewhat inadequate vocabulary) the "ideology" and its "residue". At the end of the exposition, examples are drawn from the Polynesian societies of Samoa, which illustrate the methodological arguments developed in the article. 